Nama : Wina Illirian sevi rahmadanti

NRP : 130119025 KP B

Perekonomian Indonesia

\title{
MSMEs as Economic Poles
}

Small, Micro and Medium Enterprises are basically businesses run by individuals, households, or small size business entities. Already written in Law No. 20 of 2008 on Small, Micro and Medium Enterprises. Generally MSMEs are classified based on a year's turnover limit, the amount of wealth or assets, as well as the number of employees. In Indonesia itself,MSMEs are large in the country's economy, MSMEs are the largest contributors to GDP, most absorbing labor, as well as relatively resistant to financial crises.

The year 2020 will be one of the most unpredictable years of all problems in economies around the world. The Covid-19 pandemic is one of the biggest challenges that MSMEs go through to survive today. MSMEs experience many problems such as declining sales, capital, stunteddistribution, difficulty of raw materials, declining production and labor layoffs, this problem becomes a threat to the national economy.

Indonesia's Central Bureau of Statistics explained that indonesia's economy experienced deflation of $0.1 \%$ in July 2020. In the contribution of public expenditure it appears that the total $20 \%$ of the upper class reaches $45.49 \%$, the total $40 \%$ of the middle class reaches $36.78 \%$, and the lower $40 \%$ only reaches $17 \%$. Deflation in July and August 2020 was triggered by falling prices for a number of food, beverages, and transport groups.(Tayibnapis et al., 2021)

MSMEs become squeezed into situations, where people's purchasing power is declining,and people's tendency to keep their money at home or reduce their consumptive side to future savings, because this pandemic still does not know when it will end. People tend to spend only money on basic necessities, while unplanned purchases are getting lower. The results of a survey conducted by the Central Bureau of Statistics of the Republic of 
Indonesia (September 2020) explain that there is a decrease in micro and small business income by $84 \%$ and $82 \%$ in large businesses. The sharpest declines were in the accommodation, food and beverage, services, transportation, and warehousing services, construction, manufacturing, and trade sectors. Furthermore, the survey results conducted by the Asian Development Bank (April-May 2020) in 4 countries such as Indonesia, the Philippines, Thailand, and Laos involved 3,831 MSME respondents contributing MSMEs to Domestic Products in 4 countries over 50\%. The imposition of regional restrictions had a negative impact on MSMEs, but some MES continued to operate despite a decrease in revenues of more than $40 \%$. Based on the results of the ADB survey, it can be seen that $61.1 \%$ of MSMEs in Indonesia reduced the number of workers in March 2020, 59.8\% of MSMEs reduced workers in March 2020, and 59.8\% of MSMEs reduced workers in April 2020. Largescale reductions in workers will be made march-June 2020 and continue until October 2020.(Tayibnapis et al., 2021)

MSMEs inevitably and should be required to digitize directly, but this is not as easy as imagined, still relatively low and few MSMEs who do business using technology. The fastest way is to partner with an ecommerce platform that has done business online. Digitalization must also be monitored by e-commerce parties such as ultra micro financing based on digital technology aimed at accelerating financial penetration and inclusion, because there are still many micro-businesses that have difficulties such as accessing bank financing, hard-to-reach locations and very small business scale.(Tayibnapis et al., 2021)

MSMEs become a pillar in the Indonesian economy because it absorbs a lot of labor, expands employment, and becomes a provider of security for low-income people in a productive economy. One of the advantages in MSMEs is the ease in adopting and implementing new technologies and innovations in business. MSMEs also do not have complex organizational and bureaucratic structures, and business flexibility that can adjust circumstances and places. 


\section{DAFTAR PUSTAKA}

Tayibnapis, A. Z., Wuryaningsih, L. E., \& Gora, R. (2021). Medium, Small and Medium Enterprises and Digital Platforms. South Asian Journal of Social Studies and Economics, 10(2), 10-19. https://doi.org/10.9734/sajsse/2021/v10i230258 